\title{
WhatsApp: How it is Used to Support the Blended Learning in Linguistics and Research Classes in the Pandemic-Era Classroom
}

\author{
Sawirman $^{1, *}$

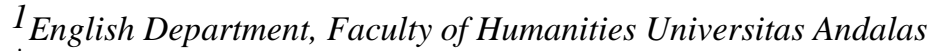 \\ *Corresponding author. Email: sawirman@hum.unand.ac.id
}

\begin{abstract}
In the new global classrooms, WhatsApp mobile application has become a central issue for the learning process. This paper attempts to show how WhatsApp Group (WAG) can support blended learning in linguistics and research classes. A qualitative case study was used. The data were drawn from 85 individuals, of whom were semantics, ecolinguistics, discourse, and research classes. Other instruments, such as recording and existing documents, were also applied. The implementation of these models in describing individual process behaviors is in the even semester of 2019/2020. This case study confirms the importance of WAG clear rules and directions of online contact hours related to general information, the making of WhatsApp group (WAG), videos, and the contact hour, participant.
\end{abstract}

Keywords: WhatsApp group, Blended learning, Linguistics Classes, Asynchronous

\section{INTRODUCTION}

Both concepts and the meaning of digital literacy have changed [1]. A lecturer does not tend to display the manual library for the last nine years. Most of these textbooks are now well kept in the notebook. Nine years ago, the students still used a lap-top to see e-book, but now almost all students avert to a digitized cellular phone. That is why the blended learning model in the related aspects is expected to contribute to the teaching and learning process [2], [3].

Blended learning can be divided into two types, namely, flipped class and flex class. The flipped learning is as a popular alternative model in recent years [4], [5], [6]. WhatsApp is one of the popular applications to support blended learning, particularly the flipped class [7]. Not just for personal messaging, WhatsApp chats, voices, and group functionalities also make it a valuable communication tool for the teaching and learning process [9], [10], [11]. The problem is how WhatsApp can be applied to support linguistics and research classes.

The extension of linguistics and research classes toward a blended learning model, mainly flipped and flex classes, are considered necessary. These two models are truly popular recently. They do not only offer an independent learning but could also utilize numerous online sources either the one under Intellectual Property Rights or non (IPR), for the need of learning both inside and outside class. In other words, these two models are oriented to the needs of society, graduation users, and oriented learning strategy in such a way the students might make both materials (content) and pedagogic tasks as the vehicle in the real tasks.

\section{THEORY AND METHOD}

WhatsApp is one the famous messaging applications nowadays. WhatsApp was created by Yahoo employees, Brian Anton and Jan Koom in 2009. It was supported by one of Silicon Valley's investors' holding companies, Major Sequoia. Although WhatsApp today is an instant messaging application for smartphones, it is derived from the English phrase, what's up?. What's upin English means what's new. WhatsApp users can exchange text messages, voices, images, videos, audio, maps, and location [9]. Anton and Koom's idea of development stands today was acquired by Google. Today, hundreds of millions are listed as active monthly users. 
Apart from it, an updated lesson plans and sufficient handbooks were extended in some ways, particularly WhatsApp mobile application. WhatsApp can send text messages, voices, and images and send video, audio slides, documents, links of both instrument and software, and even location [12], [13]. It is one of the reasons why WhatsApp is assumed as one of the interesting media and one of the driving factors of blended learning. The statement is supported by [12]. He suggested that students' engagement through mobile technologies influences not just their motivations but also social interactions. In a similar case in Malaysia, [13] outlined specific pedagogical implications for the future use of WhatsApp mobile application in the teaching and learning process.

Previous studies have shown the effectiveness of Whatsapp in learning activities. Despite critics toward learning [10], Whatsapp can developoral skills [5]. WhatsApp use in clinical practice can explore perceived benefits [6]. Whatsapp can extend the learning process in a blended classroom environment [7].Whatsapp can enhance English and foreign language learning $[14,15]$. At least, a clear benefit of WhatsApp in the teaching and learning process could be identified. WhatsApp not just easy to use but also can facilitate online collaboration and cooperation among online students and lecturers in a flipped class lecture.

Learning materials such as e-books, e-journal, photos, videos, voices, and other icons and comments can be shared with WhatsApp Group. Furthermore, It may be that these students benefitted from the ability to create and publish their work in the group, for instance, a class publication, knowledge share, class creativity, unique videos, and other novelties. As suggested by Barhoumi [9], 'Discussions are related to the course content taught $100 \%$ in-class'. The problem is how to apply this application to Linguistics and research classes.

The use of qualitative case studies is a wellestablished approach in a small group of undergraduate and postgraduate students in a university. The WhatsApp group model is one of how that could be empowered. The implementation of these blended learning for subjects, mainly, for the semester learning in the even semester of 2019/2020. Case studies have been long established in describing the process of individual behaviors to present a detailed analysis. By the end of the semester period, data were collected from 85 individuals: semantics, ecolinguistics, discourse, and research classes. Other instruments, such as recording and existing documents, were also applied.

\section{RESULT AND DISCUSSION}

Several following steps are only the developing model of linguistics and research classes based upon WhatsApp group under asynchronous techniques during14 times contact hour. This subchapter describes the procedures and examples used in linguistics and research classes.

\subsection{Pre-classes}

Before the class begins, some directions of online contact hour via WhatsApp are needed regarded to online contact hour related to general information, the making of WhatsApp group (WAG) info, lesson plans, paper rubrics, slide rubrics, video rubrics, and the contact hour participant info. For some linguistics and research classes, especially, I have used some directions to my students before the class begins.

1. Set up a group in WhatsApp application whose members consisting of both students and lecturers convening the subject.

2. Make paper, slide, and video of course material presentation from the field data and/or article of book chapters or journal according to the direction of the convening lecturer (Figure 1).

3. Both paper and slide have a particular format (enclosed). To ease the evaluation, both paper and slide must be sent to drsawirman@gmail.com punctually (Figure 2).

4. Either convening lecturer or student(s) is appointed to play the role of the facilitator during discussion running in the WAG class.

5. All of the course material already presented in the online contact hour deserves a test either during formative or summative, 
midterm test or final test term, quiz, and the application in the real-world (real tasks).

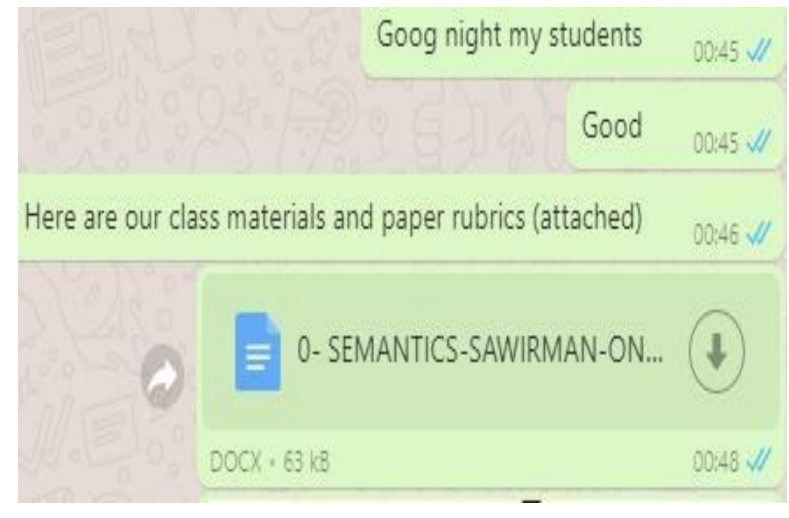

Figure 1 Lecturer's greeting before the class starts

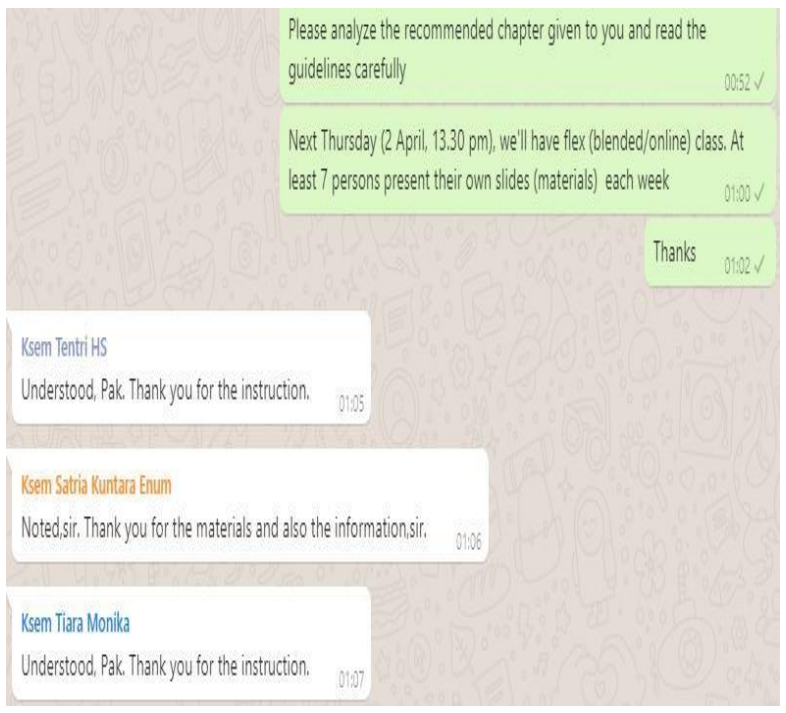

Figure 2 Recommended materials share

Every student must send the assignment by themselves and through their own email address. Assignments that are sent collectively and/or through friends' email will not be considered. Therefore, every student must have their own email address.

Figure 3 Assignment direction

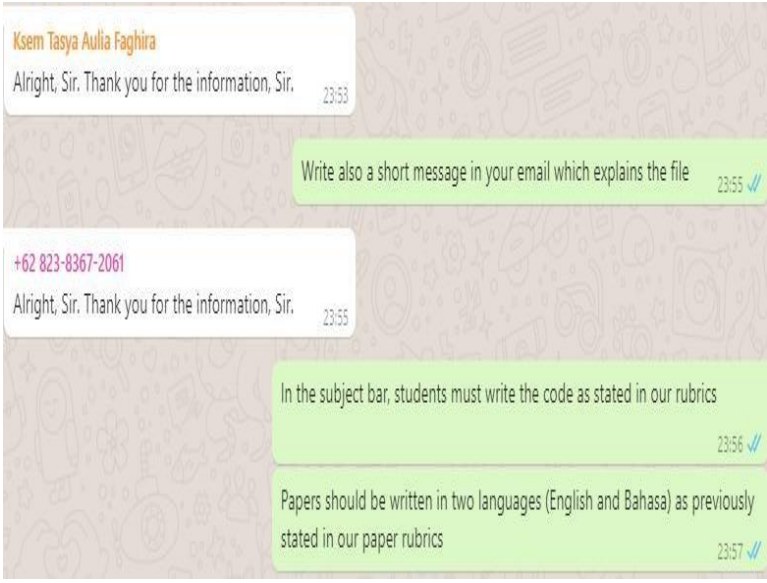

Figure 4 Students' feedbacks and lecturer's direction

\subsection{The making of WhatsApp group (WAG) procedures}

1. The WAG is set up by the convening lecturer or the student representing the class.

2. The administrator confirms the full names of all lecturing participants registered in the WAG.

3. If there is a number without a name in the WAG, thus, the administrator or the student concerned should write on his/her name individually by clicking setting, click profile, rename menu "about," and please change the WA status usually written available or at a gym etc. with your name in full (not an alias).

4. In order to make grouping and searching, WAG's course names must be made under several indicators: (a) all course names must be written in a capital letter; (b) please combined the abbreviation CLASS into (C) and the abbreviation of STRATA into (S1/S2/S3) without space (e.g., CS1, CS2, CS3); (c) add SUBJECT NAME and (d) put on CLASS CODE (e.g., A or B, 01 or 02, Reg. or FT).

5. When the subject name is more than two words, it must be abbreviated into the first letter of each word, primarily the content words (not the function words), e.g., subject of INTRODUCTION TO DISCOURSE ANALYSIS is abbreviated into IDA, INTRODUCTION TO SCHOOLS OF LINGUISTICS is abbreviated into ISL, and 
so on.

6. Several examples of name WAG: CS1 SEMANTICS A or CS2 ECOLINGISTICS or CS2 FORENSIC LINGUISTICS or CS2 ECOLINGUISTICS 02 or $\mathrm{CS} 2$ ECOLINGUISTICS REG (abbreviated from regular class) or CS2 ECOLINGUISTICS FT (abbreviated from class Fast Track) or CS1 SEMIOTICS, CS1 IDA A, or CS1 MPK B, and so on.

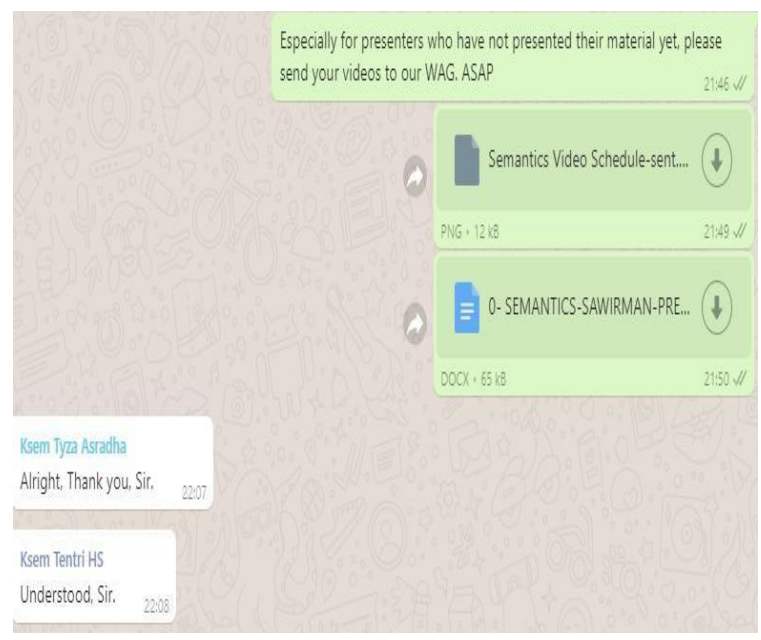

Figure 5 Assignment instruction

\subsection{Video presentation procedures}

1. The video content must come along with the material offered by the lecturer (team), and it must come together with both paper and slide already sent to the e-mail the weeks before.

2. The technique of video making is not reciting either the paper or the slide. The participant will acquire a low score when this is done.

3. The video is made to run in a duration of 5 minutes. The video made through a combination of cover, photo, writing, voice, and /or animation will be given a special point (extra score).

4. The presentation video cover contains several points, as follows. Firstly, THE VIDEO TITLE. It has to run together with the language used. When the language is used in English; thus, the video title must be in English, too, for instance, The Areas of Ecolinguistics, Qualitative Research, etc. When the video is in Indonesian, the title should also be in Indonesian, such as
Cakupan Kajian Ekolinguistik, Penelitian Kualitatif, etc. Secondly, it is obligatory to stipulate the name of the supervising lecturer: Dr. Sawirman, M.Hum. Thirdly, it is obligatory to stipulate the name of the video maker. Concerning the video selected, it will be uploaded to YouTube; thus, it is needless to use the student's registration number (NIM). Fourthly, please stipulated the name of department, faculty, and university as well as year of video made, for instance, Jurusan Sastra Inggris (English Department), Magister Linguistik (Postgraduate of Linguistics), Fakultas Ilmu Budaya (Faculty of Humanities), University of Andalas, 2020.

5. The presenter is necessary to put on an introduction about the video mentioning the name of the video maker and the supervisor's name, too, for instance, "I am Angkasa supervised by Bapak Dr. Sawirman will present Fairclough's Critical Discourse Philosophy to you" and the like or it may be in an attractive semi-formal, for example, $\mathrm{Hi}$ Guys, under Bapak Dr. Sawirman supervision, I am Angkasa would expose Fairclough's Critical Discourse Philosophy.

6. The presenter's video is uploaded to the WhatsApp group in time mainly set up according to class condition, student number (group), and a number of contact hours.

7. The e-learning activity could be done in two learnability forms, namely synchronous moment (time of contact hour is the same as/simultaneous with and different place) and asynchronous one (time of contact hour is not the same as and different place/nonsimultaneous moment). We choose the second one, namely the asynchronous one (time of contact hour is not the same as and different place/non-simultaneous moment).

8. The language priority used by the presenter in the video runs together with the subject title. When the subject title is in English, for instance, Semantics, thus, the language prioritized in the video in English. When the subject title is in Indonesian, for example, Ekolinguistik, therefore, the presenter in the video may use either Indonesian or English. 


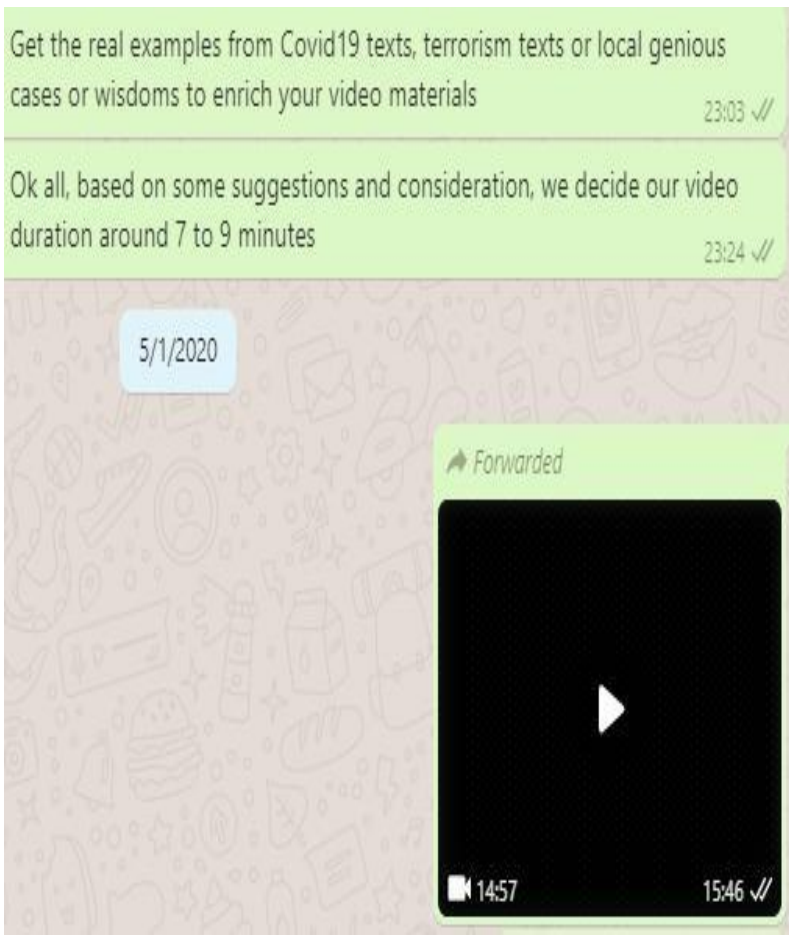

Figure 6 Lecturer's direction

\section{+62 852-6400-3526}

understood, Sir. Thank you for giving us the example, Sir.

Ksem Tyza Asradha

Alright, thank you for sharing us the example, Sir.

Figure 7 Student's feedback

\subsection{The contact hour participant}

1. All of the contact hour participants are obliged to ask questions or respond to the presenters (individually or in a group) minimally 5 (five) times during the online contact hour marking the participant's presence and score of class activity. The weight of a question is maximally 20 points. When a participant, for example, ask questions 5 (five) time, thus, his/her maximal score 5 X $20=100$ points. For the participant asking questions more than 5 (five) times; thus, the questions to be scored are the five best questions having the highest points

2. The characteristic of a question having a high point is the one carries critical substance and analysis from reliable sources such as to CRITICIZE or to ADD INFORMATION or to ADD EXAMPLE or to DENY and the like.

3. The one asking question(s) should mention or write down his/her name in full either individual or in the group asked while mentioning the name of who asked the question, for instance, "I am Muhammad Angkasa wanting to ask a question(s) to Alana Lovelyanita about" or "I am Arya wanting

to criticize Cynthia about.... or I am Muhammad Angkasa would like to add Caca Alisa Flora's statement on ...." or I am Caca wishing to add example(s) in the local language in Alisa Flora's paper about" and the like.

4. The presenter(s) (either individual or in the group) receiving question(s), criticism, or input have(s) to answer it depends on reliable sources.

5. The contact hour participants asking a question(s) are obliged to re-respond the reanswer brought forward by the presenter (individually/in the group), for instance, "I agree with Alana's question that or "I do not understand comprehensively Alisa's answer mainly the aspect of", and the like.

6. Either question or answer may make use of text or voice messages or may also be with the auxiliary of emoticon of raise hand, thumb, like a marker, and the like. The following model is one of the example texts that use voice messages in a WAG discussion.

7. Use an understandable formal language by all WAG participants while eschewing the universal ethical violating expressions as stated on Information and Electronic Transaction Law (abbreviated as UU ITE in Indonesia).

8. The answers of contact hour participants in a text may be supported by other resources or links from video provided that all rights preserved and academic etiquette are put into account. We work online. We must take precautions against plagiarism. All data might be viral just in a count of a couple of minutes. 


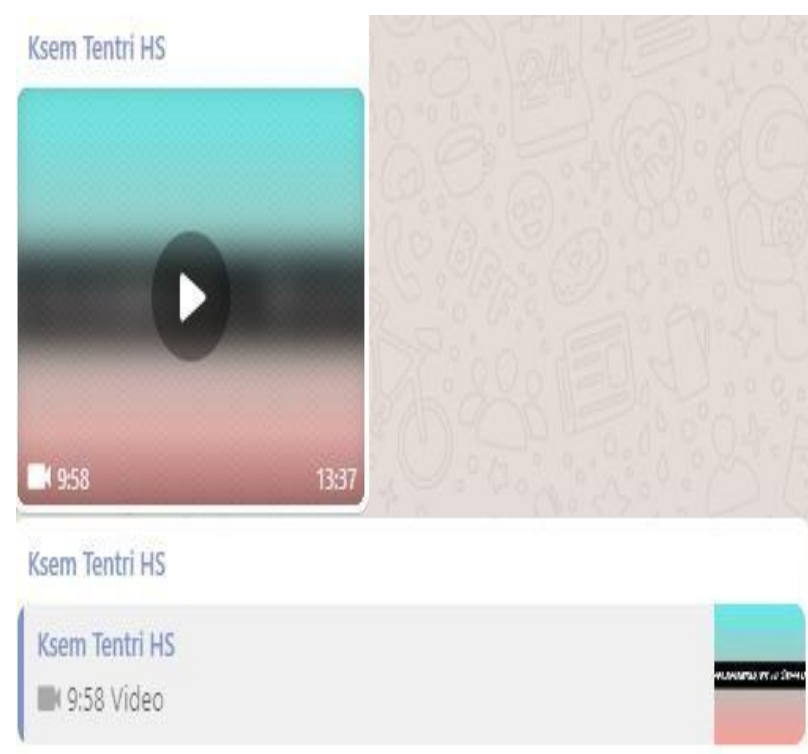

Assalamu'alaikum.

Dear Sir and my friends,

My name is Tentri Hari Sapira (1710732003) with attendance list number 14. Here is my video presentation about Complementaries, happy watching all (1)

Figure 8 Student's video sharing

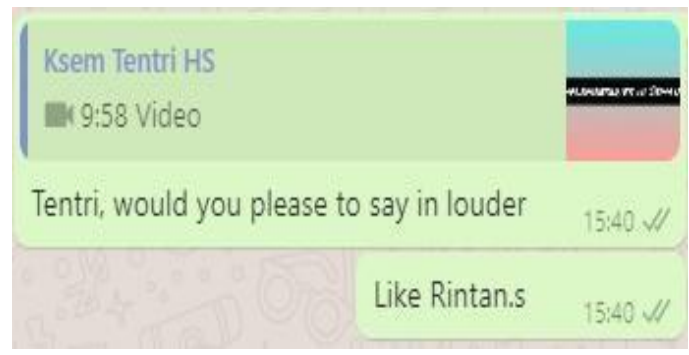

Figure 9 Lecturer's video feedback

\section{$+62852-6400-3526$}

QD Dear, friends according to our online class format, everyone is required to ask at least 5 times during our online class. (III. 20) So, for those who have questions feel free to post it in this group either in te..

㲅组绝, thanks Sutchi

Figure 10 Peer review feedback

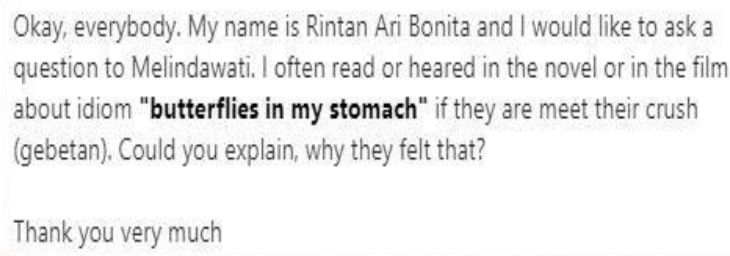
question to Melindawati. I often read or heared in the novel or in the film about idiom "butterflies in my stomach" if they are meet their crush (gebetan). Could you explain, why they felt that?

Thank you very much

\section{+62 852-6400-3526}

Ksem Semiotic Rintan 2019

Okay, everybody. My name is Rintan Ari Bonita and I would like to ask a question to Melindawati. I often read or heared in the novel or in the film about idiom "butterflies in my stomach" if they are meet their crush (gebetan). Could you ...

Okay, Rintan. Thanks for your question.

Dear, @Ksem Melinda it's your time to answer $d$

Ksem Semiotic Rintan 2019

And the next question to Tuti Handayani. I would like to ask about why you choose sparrow as the best represents for category of birds?

Thankyou very much

Figure 11 Students' questions 


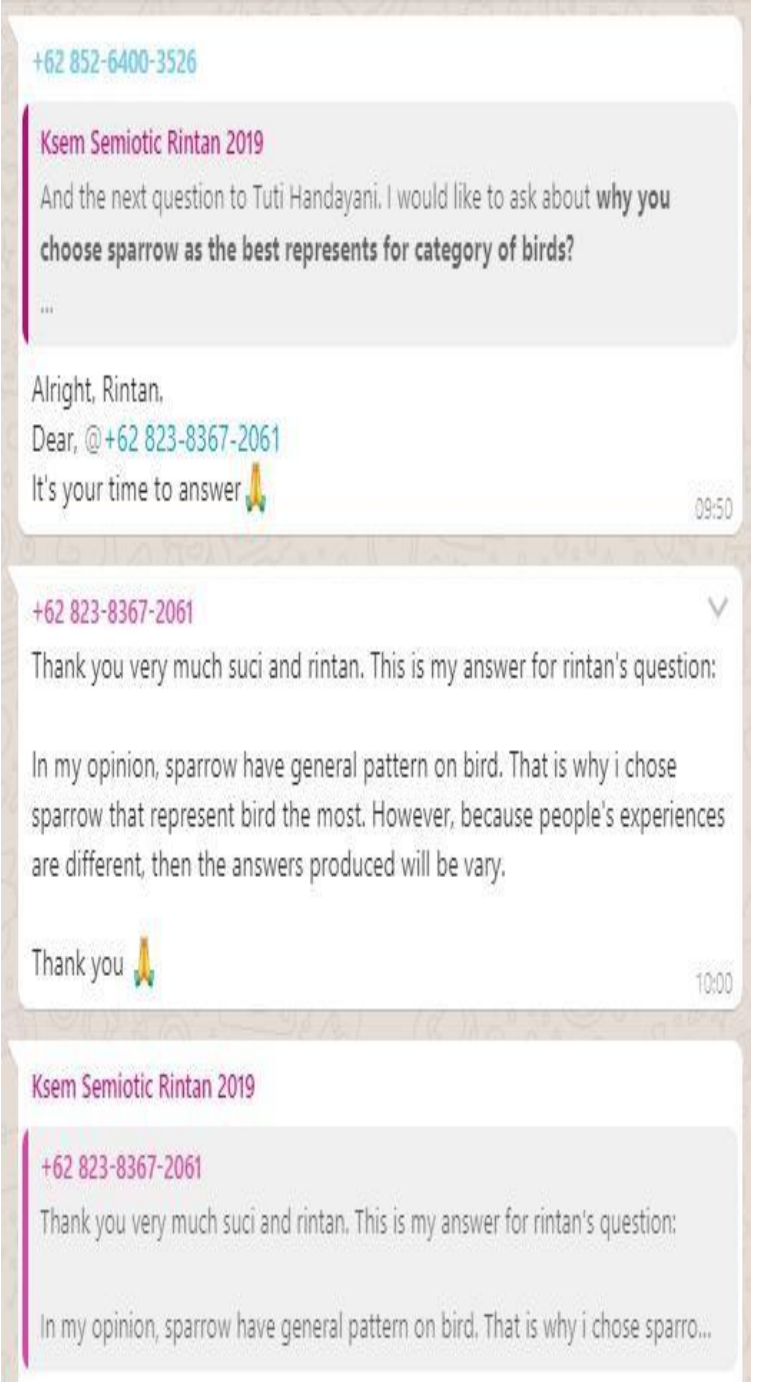

Figure 12 Students' answers

$+62823-8367-2061$

Ksem Zila
Good afternoon, Sir and friends.
My name is Nazila Maulidia Sari. I would like to ask Tuti Handayani regarding ...

Thank you nazila for the question. This is my answe:

In my opinion, individual perspectives surely matter on decide which one is the best word to represent since it was related to meaning of a word.

Thank you
Ksem Semiotic Irma 2019

Alright.

So, It can be conclude that hyponymy is the name of the member, and prototype which is the best represent for the category.

Thank you Tuti.

Figure 14 Students' answers

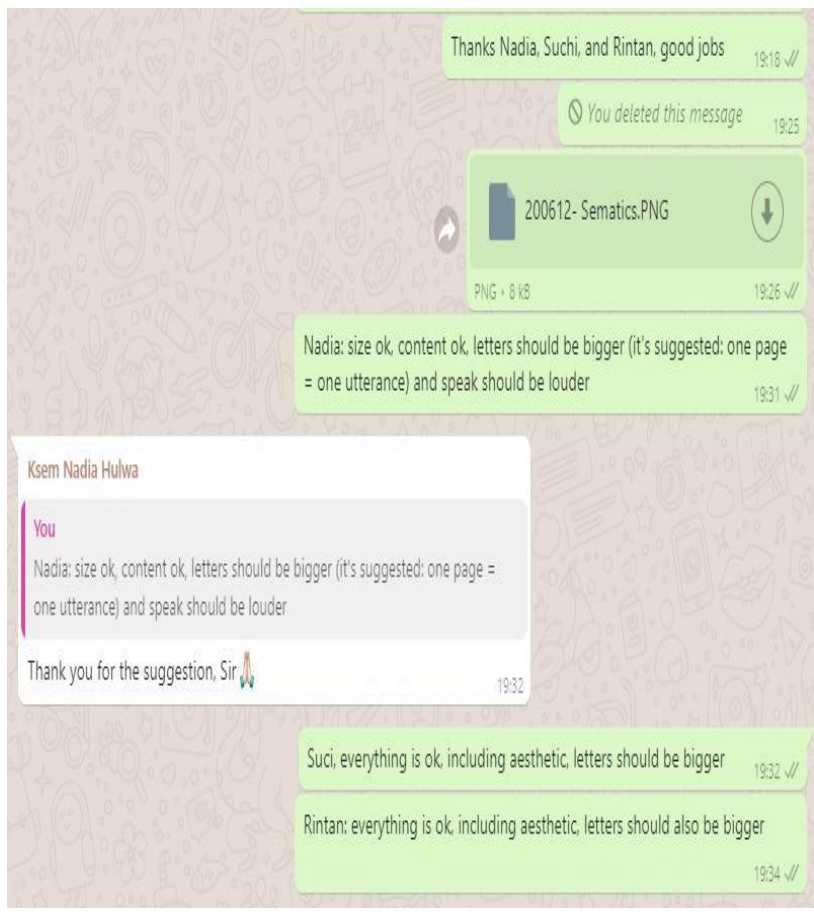

Figure 15 Lecturer reinforcement

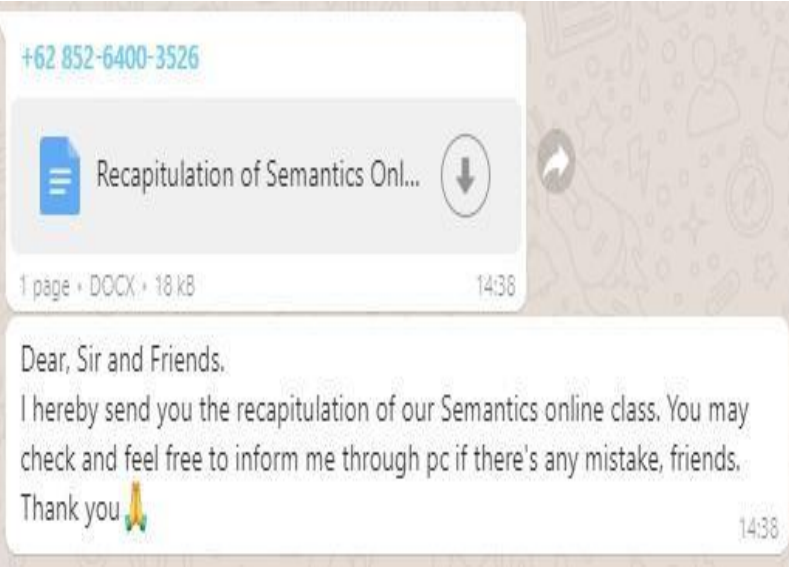

Figure 16 Recapitulation of online class

Figure 13 Students' answer 


\section{CONCLUSION}

WhatsApp chats, voices, images, icons, location, and group functionalities can help students learn in an asynchronous blended learning classroom, particularly in linguistics and research classes. Video, audio slides, documents, links of both instruments and software sent to WhatsApp are also a valuable communication tool for the teaching and learning process to support linguistics and research classes. However, some procedures on the previously mentioned should be undertaken after the association between lecturer and class members. It is also suggested that before those procedures are introduced, a course contract, lesson plan, and other additional rubrics such as paper rubrics, slide rubrics, and video rubrics should be socialized to the students.

\section{ACKNOWLEDGMENT}

I am grateful to the LP3M of Universitas Andalas for financial support through the scheme of the Education Development and Quality Assurance Research (PPMP) in the year 2020.

\section{REFERENCES}

[1] G. Akçayır \& M. Akçayır. "The flipped classroom: A review of its advantages and challenges," Computers \& Education, vol. 126, 2018, pp. 334-345, doi:10.1016/j.compedu.2018.07.021

[2] I. T. Awidi \& M. Paynter. "The impact of a flipped classroom approach on student learning experience," Computers \& Education, 2018, doi:10.1016/j.compedu.2018.09.013

[3] L. Calimeris. "Effects of flipping the principles of microeconomics class: Does scheduling matter?," International Review of Economics Education, 2018 doi:10.1016/j.iree.2018.01.002.

[4] Sawirman. "Flipped Class Contributes to the Development of Awareness Centered Learning and Helps the Linguistic Students Create Their Own Innovation," $2^{\text {nd }}$ ICED-QA Proceeding, 2019.

[5] A.A. Vaca \& M.S. Cruz-Martinez. "Mobile instant messaging: Whatsapp and its potential to develop oral skills," Media Education Research Journal, vol. 50, ed. XXV, 2017, pp. 43-52.
[6] K. Ganasegeran, P. Renganathan, A. Rashid \& S. A. R. Al-Dubai. "The m-Health revolution: Exploring the perceived benefits of WhatsApp use in clinical practice," International Journal of Medical Informatics, vol. 97, 2017, pp. 145151 .

[7] N. Annamalai. "Using Whatsapp to Extend Learning in a Blended Classroom Environment," Teaching English with Technology, vol. 19, ed. 1, pp. 3-20. [Online]. Available: http://www.tewtjournal.org

[8] H.Lucida. "Kata Pengantar". In Panduan Hibah Penelitian Pengembangan dan Penyelenggaraan Blended Learning (PPBL) Tahun 2020. Padang: LP3M Universitas Andalas, 2020.

[9] C. Barhoumi. "The Effectiveness of WhatsApp Mobile Learning Activities Guided by Activity Theory on Students' Knowledge Management," Contemporary Educational Technology, vol. 6, ed. 3, 2015, pp. 221-238.

[10] G. Awada. "Effect of WhatsApp on critique writing proficiency and perceptions toward learning," Cogent Education, vol. 3, ed. 1, 2016, pp. 1-17.

[11] P. Ayuningtyas. "Whatsapp: Learning on the Go," Metathesis: Journal of English Language Literature And Teaching, vol. 2, ed. 2, 2018, pp. 159-170.

[12] A. B. Amry. "The Impact of WhatsApp Mobile Social Learning in the Achievement and Attitudes of Female Students Compared with Face to Face Learning in The Classroom," European Scientific Journal, vol. 10, ed. 22, 2014.

[13] Sawirman. "The Development of Discourse Lesson via Peer Learning and Cultural Studies," in Improving Educational Quality Toward International Standard - Volume 1: ICEDQA, 2018, pp. 111-113.

[14] A. Wijaya. "Students' Responses toward the Use of Whatsapp in Learning," Journal of Teaching \& Learning English in Multicultural Context, vol. 2, ed. 1, pp. 47-55.

[15] M.M. Hamad. "Using Whatsapp to enhance students' learning of English language -experience to share". Higher Education Studies, vol. 7, ed. 4, 2017, pp. 74-87 